\title{
Arsenic interactions with bog iron ores - As(III) and As(V) adsorption-desorption study
}

\author{
Magdalena Tuchowska ${ }^{1}$, Tomasz Bajda ${ }^{1}$, Grzegorz Rzepa ${ }^{1}$, Klaudia Dębiec ${ }^{2}$, \\ Łukasz Drewniak ${ }^{2}$
}

${ }^{1}$ AGH University of Science and Technology, Faculty of Geology, Geophysics and Environmental Protection;
al. A. Mickiewicza 30, 30-059 Krakow, Poland, e-mail: magdalena.tuch@gmail.com
${ }^{2}$ University of Warsaw, Faculty of Biology, Laboratory of Environmental Pollution Analysis;
ul. Miecznikowa 1,02-096 Warsaw, Poland

(C) 2016 Authors. This is an open access publication, which can be used, distributed and reproduced in any medium according to the Creative Commons CC-BY 4.0 License requiring that the original work has been properly cited.

Arsenic is a toxic element, elevated concentration of which in the environment can result from both anthropogenic activity and natural geochemical processes. The contamination of water, especially groundwater, with As has been recognized as a major environmental problem (Choong et al. 2007). The mobility and toxicology of As is related to its valence state which can be (+III) or (+V), depending mainly on $\mathrm{pH}$ and redox conditions. Because even low As concentrations in drinking water causes severe health effects, the technologies of its effective removal are thought to be very important (Mohan \& Pittman 2007). Among many methods developed for removing aqueous arsenic species, the adsorption onto iron oxyhydroxides or oxyhydroxide-rich sorbents is one of the most effective. Despite many studies, the factors affecting the adsorption processes, especially those related to the sorbent properties, are still far from being fully understood (e.g. Adra et al. 2016). In this work we investigated As(III) and $\mathrm{As}(\mathrm{V})$ adsorption and desorption by bog iron ores - natural ferruginous sediments which have been recently demonstrated to exhibit very good sorption properties.

For this study four samples of bog iron ores, were collected at different sites in the Polish Lowlands: Kolechowice (KOL), Biadaszki (BD), Strzyżew (ST) and Dębe Małe (DM). They represent different bog iron ore types which, in spite of having diversified structures, mineral composition and, subsequently, physical and chemical properties, revealed good sorption affinities for trace elements in previous work (Rzepa et al. 2009).

In batch experiments the influence of various factors on adsorption were studied, including initial As concentrations, initial $\mathrm{pH}$ values and competitive adsorption of $\mathrm{As}(\mathrm{III})$ and $\mathrm{As}(\mathrm{V})$. The effect of initial As concentrations was studied in the range of $0.01-20 \mathrm{mM} \mathrm{As}(\mathrm{III})$ or $\mathrm{As}(\mathrm{V})$ at $\mathrm{pH}$ 7.5. The influence of $\mathrm{pH}$ was evaluated by the adsorption of $5 \mathrm{mM}$ As solution in the $\mathrm{pH}$ range of 2-12. The experiment of competitive adsorption of arsenite and arsenate was performed for various proportion of $\mathrm{As}(\mathrm{III})$ to $\mathrm{As}(\mathrm{V})$ in the range of initial concentrations $0.025-20 \mathrm{mM}$ at $\mathrm{pH}$ 7.5. The bonding strength of As with bog iron ore surface was estimated on the basis of three-step desorption experiments, which were conducted for the samples previously treated with $\mathrm{As}(\mathrm{III})$ or $\mathrm{As}(\mathrm{V})$ at $\mathrm{pH} 7.5$ and at constant $20 \mathrm{mM}$ initial concentration of arsenic. Arsenic concentrations in filtered (filter with a $0.22 \mu \mathrm{m}$ pore size) solutions after all the experiments were analyzed using AAS and UV-Vis spectrophotometry.

The results showed that arsenic sorption depends on its oxidation state. All the bog iron ores bound more As(III) than As(V). The highest amount of As(III) was sorbed by ST sample 
(458 mmol $/ \mathrm{kg})$, lower by KOL $(430 \mathrm{mmol} / \mathrm{kg}$ ) and DM $(427 \mathrm{mmol} / \mathrm{kg})$, and the lowest by $\mathrm{BD}$ $(333 \mathrm{mmol} / \mathrm{kg})$. However, in the case of $\mathrm{As}(\mathrm{V})$, the order was different: the highest amount of As was sorbed by BD sample $(264 \mathrm{mmol} / \mathrm{kg})$, lower by ST $(218 \mathrm{mmol} / \mathrm{kg})$, and the lowest by DM $(163 \mathrm{mmol} / \mathrm{kg})$ and $\mathrm{KOL}(158 \mathrm{mmol} / \mathrm{kg})$. The highest uptake (80-95\%) of As(III) was noted at lower initial concentrations, while the highest uptake (60-70\%) of $\mathrm{As}(\mathrm{V})$ was observed at higher initial concentrations. As(III) sorption effectiveness was $>80 \%$ throughout the $\mathrm{pH}$ range of 4 to 9 and was almost independent on $\mathrm{pH}$ in that range. In contrast, the $\mathrm{As}(\mathrm{V})$ sorption was higher at slightly acidic $\mathrm{pH}$ and significantly decreased in alkaline conditions. At $\mathrm{pH}$ around 3, sorption efficiency of both $\mathrm{As}(\mathrm{III})$ and $\mathrm{As}(\mathrm{V})$ decreased, which is likely due to the increased solubility of iron oxyhydroxides (Zeng, 2004). The results of competitive sorption experiments revealed that at low concentrations of both As species reduction of sorption efficiency of As(III) occurred. Sorption of As(V) was also affected, but only if amount of As(III) was higher than $\mathrm{As}(\mathrm{V})$. On the contrary, at high $\mathrm{As}(\mathrm{V})$ and $\mathrm{As}(\mathrm{III})$ concentrations, $\mathrm{As}(\mathrm{V})$ did not influence As(III) sorption, but As(III) substantially increased sorption of $\mathrm{As}(\mathrm{V})$. Desorption of arsenic by foreign ligands resulted in extraction of more than $70 \%$ of absorbed $\mathrm{As}(\mathrm{III})$ and $\mathrm{As}(\mathrm{V})$. In the absence of the exchange ligand, i.e., in deionized water, desorption of $\mathrm{As}(\mathrm{V})$ and $\mathrm{As}(\mathrm{III})$ was considerably lower, but noticeable.

This study shows that bog iron ores are very good arsenic sorbents. However, the extent of As removal seems to be affected by various factors including As species and the composition of the ores themselves. $\mathrm{As}(\mathrm{V})$ is immobilized less effectively than $\mathrm{As}(\mathrm{III})$, and the process is influenced by $\mathrm{pH}$ values. It is believed, that the uptake of As by bog ores is controlled primarily by iron oxyhydroxides, as main components of these rocks, but mechanisms predominant in As(III) and As(V) adsorption are different and affected by presence of e.g. phosphate and silicate ions (Ociński et al. 2011). There are no simple correlations between mineralogy and sorption capacity. Due to the variability in chemical and mineral composition of different types of bog iron ores, various levels of arsenic removal can be obtained. Such properties of the ores, combined with their ubiquity in many near-surface environments may be regarded as an incentive for the environmental protection practice.

This work was supported by LIDER Project No. LIDER/043/403/L-4/12/NCBR/2013 from The National Centre for Research and Development, Poland.

\section{REFERENCES}

Adra A., Morin G., Ona-Nguema G. \& Brest J., 2016. Arsenate and arsenite adsorption onto Al-containing ferrihydrites. Implications for arsenic immobilization after neutralization of acid mine drainage. Applied Geochemistry, 64, 2-9.

Choong T.S.Y., Chuah T.G., Robiah Y., Koay G.F.L. \& Azni J., 2007. Arsenic toxicity, health hazards and removal techniques from water: an overview. Desalination, 217, 139-166.

Mohan D. \& Pittman Jr.Ch. U., 2007. Arsenic removal from water/wastewater using adsorbents - A critical review. Journal of Hazardous Materials, 142, 1-53.

Ociński D., Ciechanowska A. \& Kociołek-Balawejder E., 2011, Polimery hybrydowe zawierające tlenki żelaza w usuwaniu arsenu z wód. Przemysł Chemiczny, 90/4, 526-532.

Rzepa G., Bajda T. \& Ratajczak T., 2009. Utilization of bog iron ores as sorbents of heavy metals. Journal of Hazardous Materials, 162, 1007-1013.

Zeng L., 2004. Arsenic adsorption from aqueous solutions on a Fe(III)-Si binary oxide adsorbent. Water Quality Research Journal of Canada, 39, 267-275. 